\title{
ANALISIS TEKNO EKONOMI PERANCANGAN 4G LTE DI KABUPATEN BANYUMAS
}

\author{
Abny Irawan ${ }^{1}$, Alfin Hikmaturokhman ${ }^{2}$, Dadiek Pranindito ${ }^{3}$ \\ Program Studi S1 Teknik Telekomunikasi, Purwokerto \\ 1,2,3 Institut Teknologi Telkom Purwokerto \\ Jl. D.I Panjaitan No. 128 Purwokerto, Telp: (0281) 641629 \\ 1'abnyirawan@gmail.com, ${ }^{2}$ alfin@ittelkom-pwt.ac.id, ${ }^{3}$ dadiek@ittelkom-pwt.ac.id
}

\begin{abstract}
Banyumas Regency has a very rapid development with the progress in knowledge education. The development of Banyumas Regency, it is also necessary to improve the telecommunication service that is feasible. Indosat is one of the operators of $4 G$ LTE technology developers using 1800Mhz frequency. Planning is using atoll software with reference to downlink, uplink and volume requirement of data needed by considering demography factor and projection of user in Banyumas Regency.

The calculation of LTE technology deployment scheme based on Banyumas Regency area coverage requires 124 sites, while calculation based on capacity needs 71 sites in 2016. Simulation result using atoll software shows average RSRP value $-80.9 \mathrm{dBm}$ and SINR value 0.64dB. Services at simulation atoll software that used by customers in Banyumas District is IMS Signaling 14,639 people, streaming media 34,348 people, video phone 65,731 people, real time gaming 20,637 people, video conference 66,325 people and voice over IP service 134,331 people.

CAPEX covers is eNodeB device costs, license, Installation and loan capital. OPEX includes Operational \& Maintenance, Rental backhaul, HR cost, Interconnection fee, marketing fee, general administration fee \& Frequency BHP. Depression assumption for 10 years. The funding structure is the assumption of $60 \%$ loan \& $40 \%$ own capital. The loan interest rate is $7.5 \%$ per annum with the assumption of a 5 year loan repayment. Annual tax of 25\%. WACC of $12.5 \%$. Cost benefit calculation yields $3 \%$ IRR and NPV Rp$8,729,606,072$. So the design of LTE deployment in Banyumas regency for 15 years has not received a payback period or is still a loss.
\end{abstract}

Keywords : LTE, Atoll, RSRP, SINR, CAPEX, OPEX, WACC, IRR, NPV, payback period.

\section{INTISARI}

Kabupaten Banyumas mengalami perkembangan yang sangat pesat dengan kemajuan di dunia pendidikannya. Dengan semakin berkembangnya Kabupaten Banyumas ini maka dibutuhkan pula peningkatan layanan telekomunikasi yang layak. Indosat merupakan salah satu operator pengembang teknologi 4G LTE dengan menggunakan frekuensi 1800Mhz. Perencanaan dilakukan menggunakan software atoll dengan mengacu kepada kebutuhan jangkauan downlink, uplink dan kebutuhan volume data yang diperlukan dengan memperhatikan faktor demografi serta proyeksi pengguna di Kabupaten Banyumas.

Perhitungan perancangan penggelaran teknologi LTE berdasarkan cakupan area Kabupaten Banyumas membutuhkan sebanyak 124 site, sedangakn perhitungan berdasarkan kapasitas membutuhkan sebanyak 71 site di tahun 2016. Hasil simulasi menggunakan software atoll menunjukan rata-rata nilai RSRP $-80.9 \mathrm{dBm}$ dan nilai SINR $0.64 \mathrm{~dB}$. Layanan yang dicakup oleh pelanggan di Kabupaten Banyumas pada simulasi software atoll. IMS Signaling sebanyak 14.639 jiwa, streaming media sebanyak 34.348 jiwa, video phone sebanyak 65.731 jiwa, real time gaming sebanyak 20.637 jiwa, video conference sebanyak 66.325 jiwa dan layanan voice over IP sebanyak 134.331 jiwa.

CAPEX meliputi biaya perangkat eNodeB, license, Instalasi dan modal pinjaman. OPEX meliputi Operational \& Maintenance, Sewa backhaul, biaya SDM, biaya Interconnection, biaya marketing, biaya administrasi umum \& BHP Frekuensi. Untuk umur depresisi selama 10 tahun. Struktur pendanaannya yaitu asumsi $60 \%$ pinjaman \& 40\% modal sendiri. Bunga pinjaman sebesar 7,5\% per tahun dengan asumsi masa pengembalian pinjaman 5 tahun. Pajak per tahun sebesar $25 \%$. WACC sebesar $12,5 \%$. Perhitungan cost benefit menghasilkan IRR 3\% dan NPV Rp-8.729.606.072. jadi perancangan penggelaran LTE di Kabupaten Banyumas selama 15 tahun belum mendapatkan payback period atau masih merugi.

Kata kunci : LTE, Atoll, RSRP, SINR, CAPEX, OPEX, WACC, IRR, NPV, payback period. 


\section{PENDAHULUAN}

Perkembangan teknologi telekomunikasi dan media elektronik telah memberikan berbagai kemudahan dalam penyebaran informasi serta peningkatan kualitas dan kuantitas penyampainnya.

Kabupaten Banyumas memiliki luas $1.327,60 \mathrm{~km}^{2}$ atau setara dengan $132.759,56$ ha yang terdiri dari 27 kecamatan, 301 desa dan 30 kelurahan. ${ }^{[6]}$

Long Term Evolution (LTE) merupakan perkembangan generasi ke-4 (4G) dari teknologi jaringan telekomunikasi sebelumnya yakni generasi ke-1 (1G), generasi ke-2 (2G) dan generasi ke-3 (3G) dimana teknologi $1 \mathrm{G}, 2 \mathrm{G}$ dan $3 \mathrm{G}$ sudah diimplementasikan oleh hampir semua operator telekomunikasi di Kabupaten Banyumas.

Penyediaan biaya investasi yang tinggi untuk memenuhi jaringan komunikasi nirkabel yang handal dengan kapasitas yang besar merupakan salah satu tantangan bagi operator telekomunikasi saat ini.tujuan dari penelitian yang dilakukan adalah melakukan kajian analisis kelayakan biaya CAPEX, OPEX dan NPV.

Berdasarkan acuan dan latar belakang pada penelitian sebelumnya yang dilakukan oleh Rudi Ardiyamto membahas tentang analisis tekno ekonomi LTE berdasarkan penggunaan frekuensi TDD atau FDD.[3] maka penulis berinsiatif mengambil topik dalam skripsi ini adalah "Analisis Tekno Ekonomi Perancangan 4G LTE Di Kabupaten Banyumas"

\section{DASAR TEORI}

\subsection{Long Term Evolution (LTE)}

LTE diperkenalkan satu paket dengan SAE (System Architecture Evolution) sebagai inti dari jaringan generasi ke-4 menurut standar 3GPP. SAE murni bekerja berdasarkan Packet Switch (PS), tidak ada lagi penyambungan Circuit Switch (CS) seperti pada sentral penyambungan pada generasi sebelumnya.

Pada dasarnya arsitektur LTE terdiri dari dua bagian yaitu LTE yang dikenal dengan E-UTRAN (Evolved Universal Terrestrial Radio Access Network) dan SAE sebagai jantung dari sistem LTE yang dikenal dengan EPC (Evolved Packet Core).

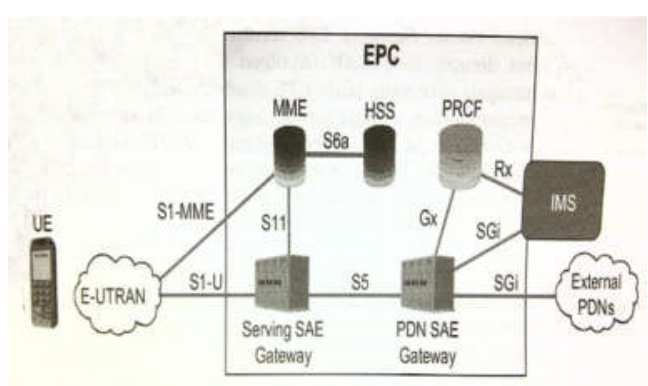

Gambar 2.1 Evolved Packet Core dalam arsitektur jaringan LTE.[7]

Pada gambar 2.1 Evolved Packet Core dalam arsitektur jaringan LTE memungkinkan terhubung langsung atau melakukan perluasan jaringan ke jaringan nirkabel lainnya.

\subsection{MIMO (Multiple Input Multiple Output)}

MIMO adalah salah satu contoh teknologi dengan kualitas yang baik dari LTE pada kecenderungan teknologi yang berkembang saat ini. Saat ini fokus adalah untuk menciptakan frekuensi yang dapat lebih efisien. Teknologi seperti MIMO dapat menghasilkan frekuensi yang efisien yaitu dengan mengirimkan informasi yang sama dari dua atau lebih pemancar terpisah kepada sejumlah penerima, sehingga mengurangi informasi yang hilang dibanding bila menggunakan system transmisi tunggal. Pendekatan lain yang akan dicapai pada system MIMO adalah teknologi beam forming yaitu mengurangi gangguan interferensi dengan cara mengarahkan radio links pada penggunaan secara spesifik. ${ }^{[7]}$ 


\subsection{OFDMA (Orthogonal Frequency}

Division Multiple Access)

Teknologi LTE Menggunakan OFDM-based pada suatu air interface yang sepenuhnya baru yang merupakan suatu langkah yang radikal dari 3GPP. Merupakan pendekatan evolusiner berdasar pada peningkatan advance dari WCDMA. Teknologi OFDM-based dapat mencapai data rates yang tinggi dengan implementasi yang lebih sederhana menyertakan biaya relatif lebih rendah dan efisiensi konsumsi energi pada perangkat kerasnya.

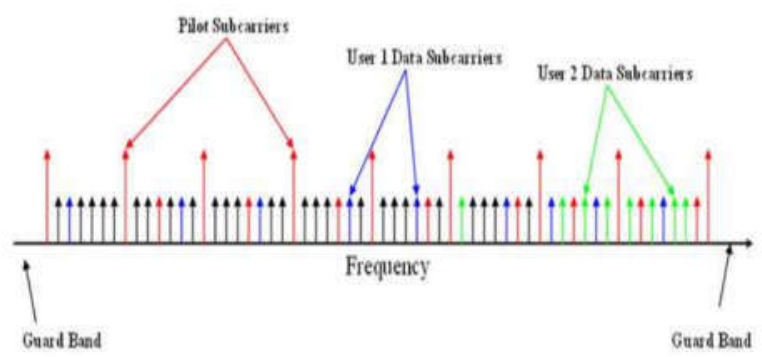

Gambar 2.2 Orthogonal Frequency Division Multiple Access. ${ }^{[7]}$

Gambar 2.2. merupakan modulasi OFDMA yang menghindari permasalahan yang disebabkan oleh pemantulan multipath dengan mengirimkan pesan per bits secara perlahan. Subkanal narrow pada OFDMA dialokasikan pada basis burst by burst menggunakan suatu algoritma yang memperhatikan faktor-faktor yang mempengaruhi RF (Radio Frequency) seperti kualitas saluran, loading dan interferensi. ${ }^{[7]}$

2.4 Adaptive Modulation and Coding $(A M C)^{[9]}$

AMC adalah salah satu teknologi pendukung LTE, digunakan untuk menentukan skema coding dan modulasi yang digunakan berdasarkan Channel Quality Indicator (CQI), CQI efektif digunakan untuk mengukur bandwidth dan kualitas sambungan (link quality) atau diukur dengan Signal To Noise Ratio (SNR).

\subsection{Perencanaan Jaringan}

Dalam perencanaan jaringan seluler ada beberapa hal yang harus diperhatikan diantaranya :

1. Kodisi geografis

Dalam penentuan ketinggian tower, ketinggian antenna, jenis antenna, penentuan link transmisi dan power supply diperlukan pengetahuan dan pengamatan kondisi geografis area tersebut agar dalam menentukan hal-hal tersebut menjadi efisien.

2. Demografi penduduk

Penempatan posisi site dan kapasitas site ditentukan oleh demografi penduduk yang menduduki area tersebut dimana daerah yang berpenduduk banyak akan diberi trafik yang lebih besar dibandingkan daerah yang berpenduduk sedikit.

3. Penentuan parameter

Penentuan parameter transmisi disesuaikan dengan beberapa faktor yaitu kondisi geografis dan kebutuhan user agar kualitas jaringannya menjadi baik dan efisien.

4. Perencanaan masa depan

Dalam peningkatan sebuah layanan perencanaan masa depan sangat diperlukan menyesuaikan dengan kebutuhan operator telekomunikasi agar dapat meningkatkan pelayanan. Perencanaan masa depan meliputi coverage ataupun penambahan site baru..

\subsubsection{Planning By Coverage}

a. Radio Link Budget

Perhitungan radio link budget dilakukan pada dua sisi downlink dan uplink. MAPL (Maximum Allowable Path Loss) terbagi menjadi dua, yaitu MAPL arah downlink dan MAPL arah uplink. MAPL merupakan nilai maksimum dari pelemahan sinyal.

- MAPL Downlink

Effective Radiated Power (EIRP) ditentukan dengan menggurangkan loss dan 
menjumlahkan gain diantara power amplifier dengan antenna ke dalam bentuk daya keluaran sebenarnya dari transmitter.

Persamaan dari EIRP arah downlink adalah sebagai berikut: ${ }^{[17]}$

$E I R P=P_{T X}+G_{T X}-L_{T X}$

Keterangan :

- $\mathrm{P}_{\mathrm{TX}}=$ Transmit RF Power $(\mathrm{dBm})$

- $\mathrm{G}_{\mathrm{TX}}=$ Transmit antenna Gain $(\mathrm{dB})$

- $\mathrm{L}_{\mathrm{TX}}=$ Transmit $\mathrm{RF}$ Line Loss (dB)

Berikutnya adalah menentukan persamaan Sentivity Receiver (SR), SR ditentukan dengan menjumlahkan nilai thermal noise, Noise figure, dan SNR. Pada persamaan 2.2 berikut ini merupakan persamaan untuk menghitung Sentivity Receiver. [17]

$S R=k T B+N F+S N R$

(2.2)

Keterangan :

- $\mathrm{k}=$ Konstanta Boltzman (1.38 x $\left.10^{-20} \mathrm{mWs} / \mathrm{K}\right)$

- $\mathrm{T}=$ Temperature $(\mathrm{K})$

- $\mathrm{B}=$ System Bandwidth $(\mathrm{MHz})$

- $\mathrm{NF}=$ Noise Figure $(\mathrm{dB})$

- $\mathrm{SNR}=$ Signal to Noise Ratio (dB)

Setelah menebtukan EIRP maka persamaan MAPL arah downlink adalah sebagai berikut :

$$
\begin{aligned}
& M A P L=E I R P-S R-L_{B V}- \\
& M_{\text {interference }}-M_{S F} \ldots(2.3)
\end{aligned}
$$

Keterangan:

- EIRP : Effective Isotropic Radiated Power (dBm)

- SR : Sentivity Receiver $(\mathrm{dBm})$

- $\mathrm{L}_{\mathrm{BV}} \quad$ :Loss Body, Vehicle, Building (dB)

- $\mathrm{M}_{\text {interference : } \quad \text { Interference }}$ $\operatorname{Margin}(\mathrm{dB})$
- $\quad \mathrm{M}_{\mathrm{SF}}:$ Log Normal Margin (dB)

- MAPL Uplink

Effective Radiated Power (EIRP) ditentukan dengan menggurangkan loss dan menjumlahkan gain diantara power amplifier dengan antenna ke dalam bentuk daya keluaran sebenarnya dari transmitter.

Persamaan dari EIRP arah uplink adalah sebagai berikut: ${ }^{[9]}$

$E I R P=P_{T X}+G_{T X}-$ $L_{T X} \ldots .(2.4)$

Keterangan :

- $\mathrm{P}_{\mathrm{TX}}=$ Transmit RF Power $(\mathrm{dBm})$

- $\mathrm{G}_{\mathrm{TX}}=$ Transmit antenna Gain (dB)

- $\mathrm{L}_{\mathrm{TX}}=$ Transmit RF Line Loss (dB)

Berikutnya adalah menentukan persamaan Sentivity Receiver (SR), SR ditentukan dengan menjumlahkan nilai thermal noise, Noise figure, dan SNR. Pada persamaan 2.5 berikut ini merupakan persamaan untuk menghitung Sentivity Receiver. ${ }^{[9]}$

$S R=k T B+N F+S N R$ (2.5)

Keterangan :

- $\mathrm{k}=$ Konstanta Boltzman (1.38 $\left.\mathrm{x} 10^{-20} \mathrm{mWs} / \mathrm{K}\right)$

- $\mathrm{T}=$ Temperature $(\mathrm{K})$

- $\mathrm{B}=$ System Bandwidth $(\mathrm{MHz})$

- $\mathrm{NF}=$ Noise Figure $(\mathrm{dB})$

- $\mathrm{SNR}=$ Signal to Noise Ratio (dB)

Setelah menebtukan EIRP maka persamaan MAPL arah downlink adalah sebagai berikut :

$M A P L=E I R P-S R-L_{B V}-$ $M_{\text {interference }}-M_{S F} \ldots(2.6)$

Keterangan:

- EIRP : Effective Isotropic Radiated Power $(\mathrm{dBm})$ 
- SR : Sentivity Receiver (dBm)

- $\mathrm{L}_{\mathrm{BV}} \quad$ Loss Body, Vehicle, Building (dB)

- $\mathrm{M}_{\text {interference } \quad \text { :Interference }}$ $\operatorname{Margin}(\mathrm{dB})$

- $\mathrm{M}_{\mathrm{SF}} \quad$ : Log Normal $\operatorname{Margin}(\mathrm{dB})$

b. Propagasi

Model

Propagasi

diperlukan dalam perencanaan jaringan berdasarkan cakupannya, berikut ini adalah penjelasan model propagasi.

- Cost 231 ${ }^{[4]}$

Model propagasi cost 231 merupakan pengembangan dari model propagasi okumura hatta. Cost 231 memiliki frekuensi kerja sampai dengan $2 \mathrm{GHz}$. Persamaan propagasi cost 231 adalah sebagai berikut.

$\mathrm{L}_{\text {Urban }}=46.3-33.9 \log \mathrm{f}-$ $13.82 \log$ the $-\mathrm{a}\left(\mathrm{h}_{\mathrm{re}}\right)+(44,9-$ $\left.6,55 \quad \log \quad \mathrm{h}_{\mathrm{te}}\right) \log _{10} \mathrm{~d} \quad+$ CM.............................. ( 2.7)

$\mathrm{CM}=0 \mathrm{db}$ untuk ukuran medium kota dan daerah suburban

$\mathrm{CM}=3 \mathrm{db}$ untuk daerah pusat kota (metropolitan)

Pemodelan propagasi Cost 231 dibatasi oleh beberapa parameter yaitu,

- $\mathrm{f}=1500 \mathrm{MHz}$ sampai 2000 $\mathrm{MHz}$

- $\mathrm{h}_{\mathrm{te}}=30 \mathrm{~m}$ sampai $200 \mathrm{~m}$

- $\mathrm{h}_{\mathrm{re}} \quad=1 \mathrm{~m}$ sampai $10 \mathrm{~m}$

- $\mathrm{d}=1 \mathrm{~km}$ sampai $20 \mathrm{~km}$

c. Perhitungan Jari-Jari Sel ${ }^{[7]}$

Terdapat beberapa hal yang berpengaruh dalam perhitungan jari-jari sel, hal tersebut adalah sebagai berikut:

\section{- Luas Cakupan Sel}

Luas cakupan suatu sel dapat diperoleh rumus sepagai berikut:

$L_{c e l l}=2,6 \times d^{2}$

Keterangan :
Lcell : Luas cakupan cell

d : radius cell

- Jumlah Sel (Jumlah eNodeB)

Jumlah sel yang dibutuhkan dapat diperoleh dari hasil bagi antara luas daerah perencanaan dengan luas cakupan suatu sel, sehingga diperoleh persamaan rumus sebagai berikut:

Jumlah eNodeB $=$

Luas Area Perencanaan

\subsubsection{Planning By Capacity}

a. Estimasi Jumlah Pelanggan ${ }^{[15]}$

Estimasi jumlah pelanggan digunakan untuk menghitung perencanaan jaringan berdasarkan kapasitas. Semakin banyak jumlah pelanggan maka semakin besar kapasitas jaringan yang disediakan Estimasi jumlah pelanggan dapat dihitung dengan persamaan sebagai berikut.

$U_{n}=U_{0}\left(1+f_{p}\right)^{n}$

Dimana,

- $U_{n}$ : jumlah pelanggan tahun ke-n

- $\mathrm{U}_{0}$ : jumlah pelanggan pada tahun perencanaan

- $\mathrm{f}_{\mathrm{p}}$ : faktor pertumbuhan pelanggan $(\%)$

- $\mathrm{n}$ : jumlah tahun prediksi

b. Kepadatan Trafik ${ }^{[18]}$

kepadatan trafik pada LTE dapat dihitung menggunakan throughput. Throughput dapat dihitung dengan menggunakan persamaan sebagai berikut:

Thp $=$ Bearer rate $\mathrm{x}$ Sessioan time $\mathrm{x}$

Session duty ratio $\mathrm{x}\left[\frac{1}{(1-B L E R)}\right] \ldots \ldots . .(2.11)$

Keterangan:

- Session time durasi per layanan

- Session duty ratio: data transmission ratio per session

- BLER : toleransi block error rate

- Bearer rate application layer bit rate 
Selanjutnya adalah perhitungan single user throughput yang dapat dihitung dengan persamaan berikut ini,

Single user throughput $=$

$\left[\Sigma\left(\frac{\text { throughput }}{\text { session time }}\right) \times B H S A \times\right.$ penetration ratio $x(1+$ Peak Average Ratio $\left.)\right]$ 3600

Keterangan:

- BHSA : Busy Hour Service Attempt

- Penetration ratio : seberapa bagus layanan dapat melayani pelanggan

- Peak average ratio : digunakan untuk mengasumsikan prosentase kelebihan beban tertinggi pada jaringan untuk mengantisipasi lonjakan trafik di suatu area.

Kemudian adalah perhitungan Network Throughput yang dapat dihitung dengan persamaan sebagai berikut:

UL Network Trhoughput $=$

total user number $x$ UL single user throughput ...(2.13)

DL Network Trhoughput $=$

total user number $x$ DL single user throughput (2.14)

Dengan,

- Total user number : jumlah user

- UL single user throughput : total throughput uplink dari satu user pada area layanan

- DL single user throughput: total user throughput downlink dari satu user pada area layanan

c. Kapasitas $\mathrm{Sel}^{[18]}$

Perhitungan capacity uplink dan downlink bisa menggunakan rumus berikut ini :

$D L$ cell capacity $+C R C=(168-36-12) \times(C b)$

$\begin{array}{lllllll}x & (\mathrm{Cr}) & x & \mathrm{Nrb} & x & C & x\end{array}$

$1000 \ldots \ldots \ldots \ldots \ldots \ldots \ldots . . .(2.15)$

$U L$ cell capacity $+C R C=(168-24) x(C b) x$

(Cr) $x$ Nrb $\times C \times 1000$.

Dengan,

- $\quad$ CRC : 24

- $\quad \mathrm{Cb} \quad$ : Code bit

- $\quad \mathrm{Cr} \quad$ : Code Rate

- $\quad \mathrm{Nrb} \quad$ : Number of Resource Block

- C : Model Antenna Mimo
Untuk menghitung julmah cell digunakan rumus berikut ini :

Jumlah cell $=$

Network throughput

$$
\text { cell capacity }
$$

Dengan,

- Network Throughput : throughput jaringan

- Cell capacity : kapasitas sel

2.6 Software Planning ATOLL

Atoll merupakan software yang digunakan untuk membuat sebuah perencanaan jaringan seluler. Atoll dapat membuat perencanaan radio secara detail dengan fitur-fitur pendukungnya.

Atoll memiliki fitur-fitur pendukung dalam merencanakan sebuah jaringan seluler agar mendekati hasil secara realistis seperti simulasi montecarlo untuk menentukan status user dan penentuan lokasi user secara acak.

2.6.1 RSRP (Reference Signal Received Power)

RSRP merupakan kuat sinyal yang diterima User Equipment (UE) pada teknologi LTE. Nilai RSRP yang merupakan power sinyal reference yang digunakan untuk menunjukan bagus tidaknya coverage jaringan pada suatu daerah.

2.6.2 SINR (Signal to Interference Noise Ratio)

SINR

perbandingan kuat sinyal disbanding dengan sinyal interferensi dari resource yang lain. Parameter ini menunjukan level daya minimum dimana user masih bisa melakukan suatu panggilan

2.7 CAPEX (Capital Expenditure) dan OPEX (Operational Expenditure)

CAPEX (Capital Expenditure) merupakan pengeluaran yang berhubungan dengan implementasi, ekspansi dan fixed asset. seperti infrastruktur jaringan, provisioning layanan baru atau penambahan pada layanan eksisting atau perbaikan bisnis perusahaan. OPEX (Operational Expenditure) menipakan pengeluaran 
yang dikeluarkan untuk menjalankan bisnis atau peralatan. dengan tujuan agar layanan tetap berjalan aktif.

2.8 Net Present Value $(N P V)^{[19]}$

Net Present Value (NPV) adalah selisih antara present value dan biaya-biaya dengan nilai sekarang dan penerimaan-penerimaan kas bersih di masa yang akan datang. [19] Untuk menghitung nilai sekarang harus ditentukan tingkat yang relevan yang berlaku sekarang sebagaimana persamaan 2.1

$$
N P V=\sum_{t=1}^{n} \frac{C F_{t}}{(1+K)^{t}}-I_{0}
$$

Dimana :

$$
\begin{array}{ll}
\mathrm{t} & : \text { jumlah tahun } \\
\mathrm{CF}_{\mathrm{t}} & : \text { aliran kas periode } \mathrm{t} \\
\mathrm{I}_{0} & : \text { Investasi tahun ke } 0 \\
\mathrm{~K} & : \text { tingkat suku bunga }
\end{array}
$$

(discount rate)

Kriteria penilaian :

1. Jika NPV $>0$, maka investasi layak.

2. Jika NPV $<0$, investasi tidak layak.

3. Jika NPV $=0$, nilai perusahaan tetap apakah investasi dilaksanakan atau tidak.

\subsection{Incremental Rate of Return (IRR) ${ }^{[19]}$} Incremental Rate of Return (IRR) digunakan untuk mencari tingkat bunga dimana nilai sekarang dari arus kas yang diharapkan di masa mendatang atau penerimaan kas sama dengan pengeluaran investasi awal dan biaya operasional. IRR dapat dihitung dengan rumus pada persamaan 2.26 berikut ini.

$$
I_{0}=\sum_{t=1}^{n} \frac{C F_{t}}{(1+I R R)^{t}}
$$

Dimana,

- $\mathrm{t} \quad$ : tahun ke

- $\mathrm{n} \quad$ : jumlah tahun

- $\mathrm{I}_{0} \quad$ : nilai investasi awal

- CF : arus kas bersih

- IRR : tingkat bunga yang dicari nilainya

Suatu investasi dikatakan layak jika nilai IRR lebih besar dari tingkat suku bunga yang berlaku, sebaliknya jika nilai IRR lebih kecil dari nilai suku bunga yang berlaku maka suatu investasi dikatakan tidak layak.

\section{PERANCANGAN TEKNO EKONOMI}

\subsection{Perancangan Jaringan LTE}

Blok diagram di bawah ini merupakan diagram perencanaan jaringan LTE dengan menggunakan software atoll 3.2.1.

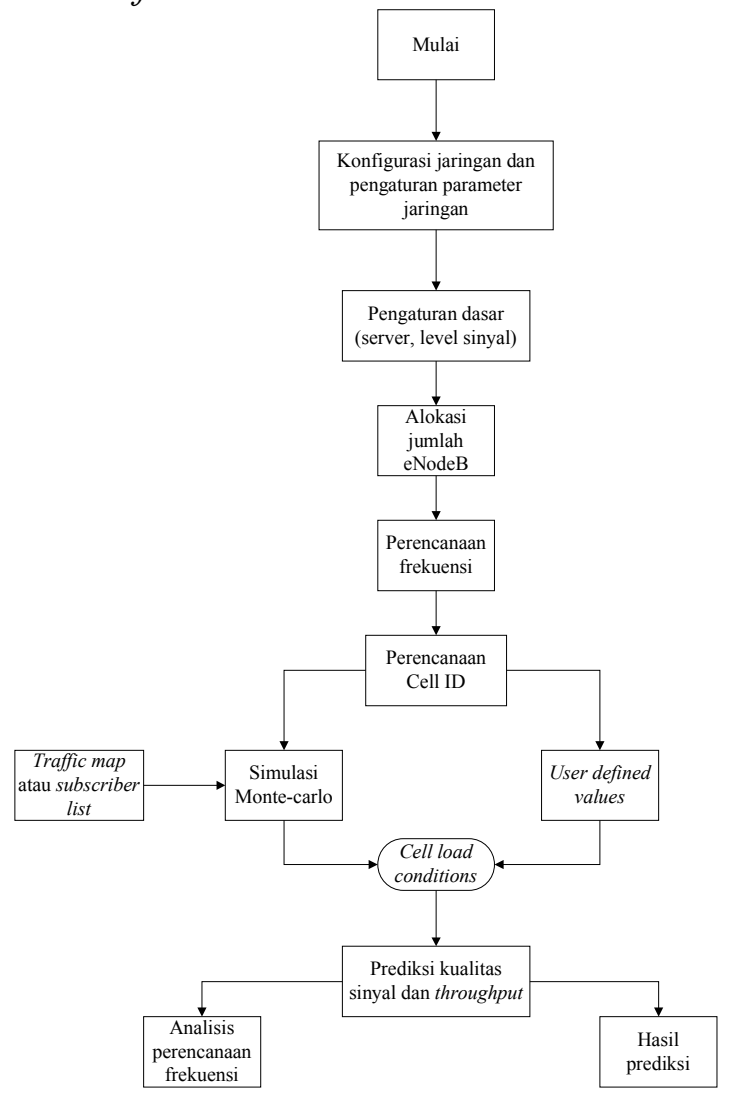

Gambar 3.1 Diagram perencanaan jaringan LTE menggunakan Atoll.

Gambar 3.1 merupakan rancangan dalam pembuatan perancangan jaringan LTE di Kabupaten Banyumas. Dalam perancangannya sesuai dengan diagram alur di atas, langkah pertama yang harus dilakukan adalah membuat project baru pada jendela Atoll 3.2.1. Langkah berikutnya adalah importing map, yang mana berkasnya dapat berformat grc (clutter), .grd (elevasi), atau .shp (vektor).

Setiap sel akan berbentuk heksagonal, yang area heksagonal tersebut dituntut untuk menutupi seluruh wilayah pada peta. Setiap eNodeB diletakkan berdasarkan daerah morfologinya, eNode B 10 Mhz Urban (3 sectors) diletakkan di 
daerah urban dan eNodeB $10 \mathrm{Mhz}$ Suburban (3 sectors) diletakkan di daerah suburban.

Konfigurasi parameterparameter yang dilakukan diantaranya konfigurasi propagasi menurut kelas-kelasnya beserta karakteristiknya, frequency band dan transmitter.Prediksi-prediksi yang dilakukan antara lain meliputi RS (Reference Signal), SINR (Signal to Interference Noise Ratio).

Konfigurasi yang dilakukan pada simulasi ini berupa karakteristik layanan, tipe mobilitas user, terminal/UE, user profile, environment, kategori UE, dan pembebebanan tiap area. Untuk karakteristik layanan disediakan hanya layanan data, karena pada LTE layanan utamanya adalah akses data.

Setelah semua konfigurasi dilakukan, simulasi Montecarlo dapat dimulai. Atoll 3.2.1 akan menentukan titik-titik pelanggan sesuai peta trafik, dari titik tersebut ditentukanlah best server dan service area. Kemudian Atoll 3.2.1 akan menghitung SINR downlink dan uplink, setelah itu throughput yang didapat setiap pelanggan ditemukan.

\subsection{Perancangan Perhitungan Tekno} Ekonomi

3.3 Jumlah penduduk Kabupaten Banyumas berdasarkan asumsi Rencana Kerja Pemerintah Daerah Banyumas tahun 2015 sebanyak 1.635.909 orang. Jumlah penduduk ini mengalami pertumbuhan sebesar $0,72 \%$. Untuk usia produktif Kabupaten Banyumas seperti yang sudah dihitung yaitu sebesar 1.089.306 jiwa, kelompok usia produktif yaitu antara umur 15 tahun sampai dengan 64 tahun. Kepadatan penduduk tersebar di berbagai wilayah di Kabupaten Banyumas untuk yang tertinggi di Kecamatan Purwokerto Utara sebesar $7.050 \quad \mathrm{Km}^{2} / \mathrm{Jiwa}$, yang terendah di Kecamatan Lumbir sebesar $430 \mathrm{Km}^{2} /$ Jiwa dan untuk rata-rata kepadatan penduduk di Kabupaten Banyumas yaitu sebesar $2.021 \mathrm{Km}^{2} /$ Jiwa.

Blok diagram di bawah ini menjelaskan tentang perancangan tekno ekonomi LTE di Kabupaten Banyumas.

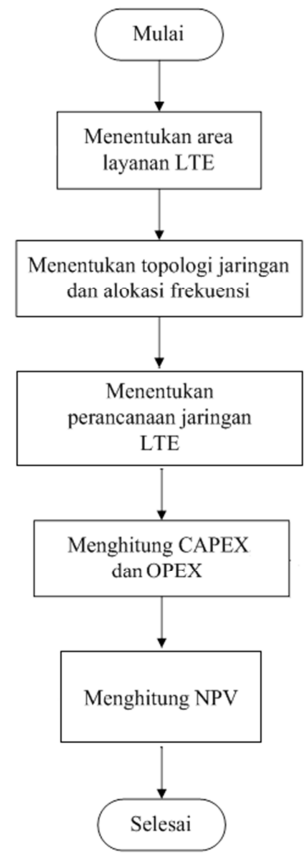

Gambar 3.2 Diagram perancangan analisis investasi LTE.

Setelah menentukan perencanaan jaringan LTE di Kabupaten Banyumas berikutnya adalah menentukan biaya Penggelaran dan operasional jaringan LTE. Seluruh biaya yang dikeluarkan dalam proyek implementasi dapat dibagi menjadi capital expenditure (CAPEX) dan operation expenditure (OPEX). CAPEX meliputi keseluruhan investasi untuk mengadakan perangkat dan sarana penunjang lainnya sesuai dengan jumlah eNodeB. Sedangkan OPEX merupakan biaya-biaya operasional yang dikeluarkan secara periodik (biasanya per bulan atau per tahun) untuk menjalankan aktifitas layanan, termasuk biaya-biaya sewa dan perijinan yang diperlukan.

Jika nilai sekarang bernilai positif, maka suatu proyek atau 
investasi dinilai menguntungkan. Sebaliknya apabila NPV bernilai negatif maka sebaiknya proyek tidak dijalankan karena tidak menguntungkan. Jika terdapat beberapa pilihan alternatif proyek maka dipilih investasi dengan investasi tertinggi.

\subsubsection{CAPEX}

CAPEX dalam perancangan penggelaran teknologi LTE di Kabupaten Banyumas ini meliputi biaya perangkat eNodeB, biaya Software/License eNodeB \& biaya instalasi eNodeB.

Biaya perangkat eNodeB berikut instalasinya diasumsikan sebesar Rp150.000.000, terdiri dari biaya perangkat eNodeB sebesar Rp140.000.000 dan Rp10.000.000 untuk biaya instalasi perangkat eNodeBnya. Biaya ini sangat murah dikarenakan untuk perangkat LTE hanya insert satu modul saja tidak memerlukan perangkat tambahan lainnya. Perancangan kali ini di asumsikan $60 \%$ dana pinjaman dan $40 \%$ modal sendiri. Dalam masa pengembalian pinjaman diasumsikan bunga pinjaman sebesar $7.5 \%$ dengan masa pengembalian selama 5 tahun.

Tabel 3.1 Komponen CAPEX

\begin{tabular}{|c|c|c|}
\hline Parameter & Value & satuan \\
\hline Inflasi & $3.35 \%$ & $\begin{array}{c}\text { per } \\
\text { tahun }\end{array}$ \\
\hline $\begin{array}{c}\text { eNodeB }+ \\
\text { Software / license }\end{array}$ & $140,000,000$ & per NE \\
\hline Instalasi & $10,000,000$ & per NE \\
\hline $\begin{array}{c}\text { Bunga pinjaman } \\
\text { Masa } \\
\text { pengembalian } \\
\text { Pinjaman }\end{array}$ & $7.50 \%$ & $\begin{array}{c}\text { per } \\
\text { tahun }\end{array}$ \\
\hline $\begin{array}{c}\text { Struktur } \\
\text { Pendanaan }\end{array}$ & 5 & tahun \\
\hline Pinjaman & $60 \%$ & \\
\hline Modal Sendiri & $40 \%$ & \\
\hline
\end{tabular}

\subsubsection{OPEX}

OPEX dalam perancangan ini meliputi biaya Operational \& Maintenance, biaya Sewa Site, biaya Backhaul, biaya gaji karyawan (SDM), Sewa Listrik, biaya Interconnection, biaya pemasaran, General \& Administrative \& BHP frekuensi.

Biaya operational \& maintenance diasumsikan sebesar Rp2.000.000, biaya sewa site diasumsikan sebesar Rp200.000.000, biaya backhaul sebesar Rp10.000.000 \& biaya BHP frekuensi Rp20.116.000.000.

Untuk biaya SDM (Sumber Daya Manusia), Interconnection, Marketing \& administrasi umum diperoleh dari data pada annual report Indosat dari tahun 2011 hingga tahun 2015. Hasil dari annual report akan dibandingkan dengan revenue Kabupaten Banyumas. Berikut data yang di peroleh dari annual report Indosat.

\subsubsection{Cost benefit Analysis}

Setelah didapat semua dasar dari penentuan nilai CAPEX \& OPEX dari 5 tahun sebelum perencanaan, berikutnya menentukan asumsi depresiasi, dimana depresiasi merupakan penurunan kualiatas suatu perangkat karena umur pemakasian, pada penelitian ini ditentukan asumsi depresiasi 10 tahun. Selanjutnya menghitung cost benefit analisis dimana tujuan akhirnya adalah menentukan nilai NPV (Net Present Value), IRR (Internal Rate of Return) \& Payback Period. 


\section{ANALISIS TEKNO EKONOMI}

4.1 Perancangan Berdasarkan Kapasitas

Perhitungan kapasitas eNodeB dirancang berdasarkan distribusi SINR per MCS yang digunakan. Karena semakin tinggi skema modulasi yang digunakan maka power yang semakin tinggi sehingga coverage semakin dekat dengan eNodeB. Pada perancangan ini menggunakan MCS index 8.

Untuk menghitung jumlah eNodeB pada perancangan berdasarkan kapasitas parameter yang dijadikan acuan adalah network throughput dan cell throughput. Jumlah cell dapat dihitung dari nilai network throughput dibagi cell throughput. Setelah angka jumlah cell sudah di dapatkan kemudian untuk mengetahui jumlah eNodeB-nya dibagi 3 karena satu eNodeB terdiri dari 3 cell. Berikut hasil prediksi jumlah eNodeB yang dibutuhkan selama 15 tahun kedepan berdasarkan kapasitas.

Tabel 4.1 Jumlah eNodeB berdasarkan kapasitas disisi uplink

\begin{tabular}{|c|c|c|c|}
\hline Tahun & $\begin{array}{c}\text { Jumlah } \\
\text { Cell }\end{array}$ & $\begin{array}{c}\text { Jumlah e- } \\
\text { NodeB }\end{array}$ & $\begin{array}{l}\text { Jumlah } \\
\text { eNodeB }\end{array}$ \\
\hline 2016 & 60 & 20.08160528 & 20 \\
\hline 2017 & 61 & 20.22619284 & 20 \\
\hline 2018 & 61 & 20.37182143 & 20 \\
\hline 2019 & 62 & 20.51849854 & 21 \\
\hline 2020 & 62 & 20.66623173 & 21 \\
\hline 2021 & 62 & 20.8150286 & 21 \\
\hline 2022 & 63 & 20.96489681 & 21 \\
\hline 2023 & 63 & 21.11584407 & 21 \\
\hline 2024 & 64 & 21.26787814 & 21 \\
\hline 2025 & 64 & 21.42100687 & 21 \\
\hline 2026 & 65 & 21.57523812 & 22 \\
\hline 2027 & 65 & 21.73057983 & 22 \\
\hline 2028 & 66 & 21.88704 & 22 \\
\hline 2029 & 66 & 22.04462669 & 22 \\
\hline 2030 & 67 & 22.203348 & 22 \\
\hline
\end{tabular}

Tabel 4.2 Jumlah eNodeB berdasarkan kapasitas disisi downlink

\begin{tabular}{c|c|c|c} 
Tahun & $\begin{array}{c}\text { Jumlah } \\
\text { Cell }\end{array}$ & $\begin{array}{c}\text { Jumlah e- } \\
\text { NodeB }\end{array}$ & $\begin{array}{c}\text { Jumlah } \\
\text { eNodeB }\end{array}$ \\
\hline
\end{tabular}

\begin{tabular}{|l|l|l|l|}
\hline 2016 & 214 & 71.3076536 & 71 \\
\hline 2017 & 215 & 71.8210687 & 72 \\
\hline 2018 & 217 & 72.3381804 & 72 \\
\hline 2019 & 219 & 72.8590153 & 73 \\
\hline 2020 & 220 & 73.38360021 & 73 \\
\hline 2021 & 222 & 73.91196213 & 74 \\
\hline 2022 & 223 & 74.44412826 & 74 \\
\hline 2023 & 225 & 74.98012598 & 75 \\
\hline 2024 & 227 & 75.51998289 & 76 \\
\hline 2025 & 228 & 76.06372676 & 76 \\
\hline 2026 & 230 & 76.6113856 & 77 \\
\hline 2027 & 231 & 77.16298757 & 77 \\
\hline 2028 & 233 & 77.71856108 & 78 \\
\hline 2029 & 235 & 78.27813472 & 78 \\
\hline 2030 & 237 & 78.84173729 & 79 \\
\hline
\end{tabular}

Dari tabel 4.1 \& tabel 4.2 dapat dilihat bahwa untuk mengcover berdasarkan kapsitas jumlah pelanggan dan kebutuhan penggunaan selulernya pada tahun 2016 disisi uplink sebanyak 20 eNodeB dan disisi downlink sebanyak 71 eNodeB. Penambahan jumlah eNodeB berbanding lurus dengan jumlah pelanggan yang terus meningkat di setiap tahunnya.

4.2 Perancangan Berdasarkan Area Cakupan

Perancangan berdasarkan area cakupan yaitu merupakan metode pendekatan dalam menentukan jumlah site agar dapat mencakup seluruh wilayah perencanaan. Dalam menentukan jumlah eNodeB diperlukan perhitungan link budget. Berikut perhitungan link budget pada perancangan penggelaran jaringan LTE di Kabupaten Banyumas.

Tabel 4.3 Uplink link budget

\begin{tabular}{|l|c|c|}
\hline Transmitter-UE & Satuan & Nilai \\
\hline Tx Power Frekuensi $1800 \mathrm{Mhz}(15 \mathrm{MHz})$ & $\mathrm{dBm}$ & 23 \\
\hline Tx Antena Gain & $\mathrm{dBi}$ & 0 \\
\hline Body Loss & $\mathrm{dB}$ & 0 \\
\hline EIRP & $\mathrm{dBm}$ & 23 \\
\hline Receiver-eNodeB & & \\
\hline Noise Figure & $\mathrm{dB}$ & 2 \\
\hline & $\mathrm{dBm}$ & $\begin{array}{c}173.977 \\
2292\end{array}$ \\
\hline
\end{tabular}




\begin{tabular}{|l|c|c|} 
SINR & $\mathrm{dB}$ & 1.263 \\
\hline Bandwidth System & $\mathrm{dB}$ & $\begin{array}{c}69.5424 \\
2509\end{array}$ \\
\hline Sencitivity Receiver & $\mathrm{dBm}$ & $\begin{array}{c}- \\
101.171 \\
8041\end{array}$ \\
\hline Interference Margin & $\mathrm{dB}$ & 1 \\
\hline Cable Loss & $\mathrm{dB}$ & 0 \\
\hline Rx Antenna Gain & $\mathrm{dBi}$ & 18 \\
\hline Fast Fading Margin & $\mathrm{dB}$ & 0 \\
\hline MAPL & $\mathrm{dB}$ & $\begin{array}{c}141.171 \\
8041\end{array}$ \\
\hline
\end{tabular}

Tabel 4.4 Downlink link budget

\begin{tabular}{|l|c|c|}
\hline Transmitter-eNodeB & Satuan & Nilai \\
\hline Tx Power Frekuensi $1800 \mathrm{Mhz}(10 \mathrm{MHz})$ & $\mathrm{dBm}$ & 46 \\
\hline Tx Antena Gain & $\mathrm{dBi}$ & 18 \\
\hline Cable Loss & $\mathrm{dB}$ & 2 \\
\hline EIRP & $\mathrm{dBm}$ & 62 \\
\hline Receiver-UE & & \\
\hline UE Noise Figure & $\mathrm{dB}$ & 7 \\
\hline Thermal Noise & $\mathrm{dBm}$ & -173.977 \\
\hline SINR & $\mathrm{dB}$ & 2.479 \\
\hline Bandwidth System & $\mathrm{dB}$ & 69.54243 \\
\hline Sencitivity Receiver & $\mathrm{dBm}$ & -94.9558 \\
\hline Interference Margin & $\mathrm{dB}$ & 4 \\
\hline Control Channel Overhead & $\mathrm{dBi}$ & 1 \\
\hline Rx Antenna Gain & $\mathrm{dBi}$ & 0 \\
\hline Body Loss & $\mathrm{dB}$ & 0 \\
\hline MAPL & $\mathrm{dB}$ & 151.9558 \\
\hline
\end{tabular}

Pada nilai transmitter pada

UE (uplink) dan transmitter eNodeB (downlink) diperoleh dari buku 4G handbook jilid 2. Pada bagian transmitter berisi parameter Tx Power Frekuensi, Tx antenna, body loss, cable loss dan EIRP.

Pada nilai receiver $\mathrm{eNodeB}$ dan receiver UE, nilai parameter noise figure, interference margin, control channel overhead, cable loss, rx antenna gain, body loss dan fast fading margin didapat dari buku 4G handbook jilid 2 . Hasil MAPL digunakan untuk menghitung jari-jari cell dan jumlah eNodeB untuk meng-cover area yang direncakanan. Untuk metode propagasi yang digunakan seperti yang telah dibahas di bab 3 yaitu menggunakan metode propagasi cost 231 .

Tabel 4.5 jumlah eNodeB sisi uplink

\begin{tabular}{|c|c|c|}
\hline \multicolumn{2}{|c|}{ COST 231 UPLINK } & Satuan \\
\hline Jari - jari cell & 1.08404544 & $\mathrm{Km}$ \\
\hline Luas cell & 3.055401744 & $\mathrm{Km}$ \\
\hline luas wilayah & 1327.59 & $\mathrm{Km}$ \\
\hline
\end{tabular}

\begin{tabular}{|c|c|c|}
\multirow{2}{*}{ Jumlah cell } & 434.5058723 & \\
\cline { 2 - 3 } & 435 & \\
\hline \multirow{2}{*}{ Jumlah eNodeB } & 144.8352908 & \\
\cline { 2 - 3 } & 145 & \\
\hline
\end{tabular}

Tabel 4.6 jumlah eNodeB sisi downlink

\begin{tabular}{|c|c|c|}
\hline \multicolumn{2}{|c|}{ COST 231 DOWNLINK } & Satuan \\
\hline Jari - jari cell & 1.16925948 & $\mathrm{Km}$ \\
\hline Luas cell & 3.554636104 & $\mathrm{Km}$ \\
\hline luas wilayah & 1327.59 & $\mathrm{Km}$ \\
\hline \multirow{2}{*}{ Jumlah cell } & 373.4812682 & \\
\cline { 2 - 3 } & 373 & \\
\hline \multirow{2}{*}{ Jumlah eNodeB } & 124.4937561 & \\
\cline { 2 - 3 } & 124 & \\
\hline
\end{tabular}

Dari tabel $4.5 \&$ tabel 4.6 terlihat untuk perhitungan jumlah eNodeB pada sisi uplink adalah 145 eNodeB dan untuk hasil perhitungan jumlah eNodeB di sisi downlink adalah sebanyak 124 eNodeB untuk meng-cover seluruh area Kabupaten Banyumas dimana luas wilayahnya $1.327,59 \mathrm{Km}^{2}$.

\subsection{Simulasi Menggunakan Atoll} Wilayah perancangan penggelaran teknologi LTE adalah di Kabupaten Banyumas. Kabupaten Banyumas terletak pada 108 39'17'109 27'15" Bujur Timur dan 795'05"7 37'10" Lintang Selatan. Luas wilayah Kabupaten Banyumas adalah $132.759 \mathrm{Ha}$ atau sekitar 4,08\% dari luas wilayah Jawa Tengah. Luas wilyah tersebut terbagi menjadi lahan sawah sekitar $32.292 \mathrm{Ha}$ atau $24,32 \%$, lahan pertanian bukan sawah seluas $51.798 \mathrm{Ha}(39,02 \%)$ dan lahan bukan pertanian seluas $48.669 \mathrm{Ha}$ $(36,66 \%) .{ }^{[6]}$ Klasifikasi wilayah di Kabupaten Banyumas diasumsikan sebagai wilayah Sub Urban dimana rata2 kepadatan wilayahnya diperoleh angka 2.021 penduduk per $\mathrm{km}^{2}$.

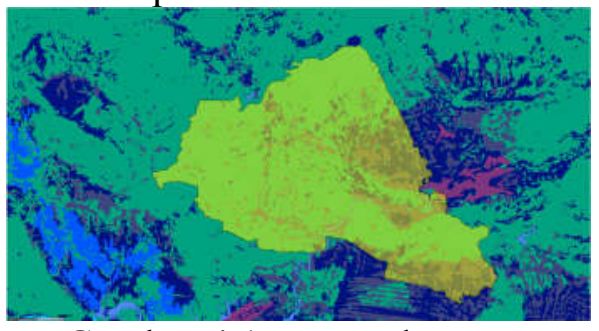

Gambar 4.1 Peta Kabupaten banyumas 
Tabel 4.7 Nilai RSRP

\begin{tabular}{|l|l|}
\hline Nilai & Keterangan \\
\hline$-70 \mathrm{dBm}$ to $-90 \mathrm{dBm}$ & Good \\
\hline$-91 \mathrm{dBm}$ to $-110 \mathrm{dBm}$ & Normal \\
\hline$-110 \mathrm{dBm}$ to $-130 \mathrm{dBm}$ & Bad \\
\hline \multicolumn{2}{|c|}{ Berikut Hasil Prediksi } \\
RSRP menggunakan software \\
atoll : \\
\\
\end{tabular}

Gambar 4.2 Prediksi coverage by

RSRP Kabupaten Banyumas

Pada prediksi gambar 4.2 RSRP divisualisasikan dalam mode warna yaitu warna biru menunjukan coverage RSRP dalam kondisi yang paling baik atau good RSRP, sedangkan untuk warna Hitam merupakan kondisi coverage RSRP paling jelek atau bad RSRP. Untuk reratanya dapat dilihat pada hasil grafik histogram berikut ini :

Dari hasil gambar 4.2 menunjukan bahwa coverage RSRP berada di-range $-60 \mathrm{dBm}$ hingga $110 \mathrm{dBm}$. Hal tersebut menunjukan hasil coverage by RSRP cukup bagus dimana mean dari hasil keseluruhan bernilai $-80.9 \mathrm{dBm}$.

SINR memberikan informasi berupa pada coverage dan throughput yang diharapkan. Semakin bagus SINR maka semakin bagus throughput yang dihasilkan pula. Berikut tabel nilai SINR :

Tabel 4.8 Nilai SINR

\begin{tabular}{|l|l|}
\hline Nilai & Keterangan \\
\hline $16 \mathrm{~dB}$ s/d $30 \mathrm{~dB}$ & Good \\
\hline $1 \mathrm{~dB}$ s/d $15 \mathrm{~dB}$ & Normal \\
\hline$-10 \mathrm{~dB}$ s/d $0 \mathrm{~dB}$ & Bad \\
\hline
\end{tabular}

Berikut Hasil Prediksi SINR menggunakan software atoll :

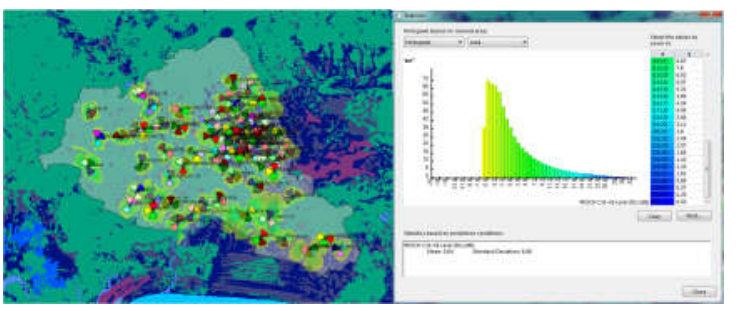

Gambar 4.3 Prediksi coverage by

SINR Kabupaten Banyumas

Pada gambar 4.3

menunjukan coverage SINR di Kabupaten Banyumas ditandai dengan warna biru sebagai kondisi coverage SINR paling bagus atau good SINR, sedangkan untuk warna merah sebagai kondisi coverage SINR paling jelek atau bad SINR. Nilai SINR dikatakan bagus pada kondisi $16 \mathrm{~dB}$ sampai dengan $30 \mathrm{~dB}$, untuk kondisi SINR normal pada kondisi $1 \mathrm{~dB}$ sampai dengan $15 \mathrm{~dB}$ dan untuk nilai SINR dalam kondisi jelek berada di bawah $0 \mathrm{~dB}$.

Dari hasil grafik histogram gambar 4.3 menunjukan bahwa coverage SINR dalam kategori normal SINR untuk rerata secara keseluruhan dikarenakan nilai reratanya $\quad 0,64 \mathrm{~dB}$. SINR dipengaruhi oleh jarak user, semakin jauh jarak user maka SINR mengalami penurunan.

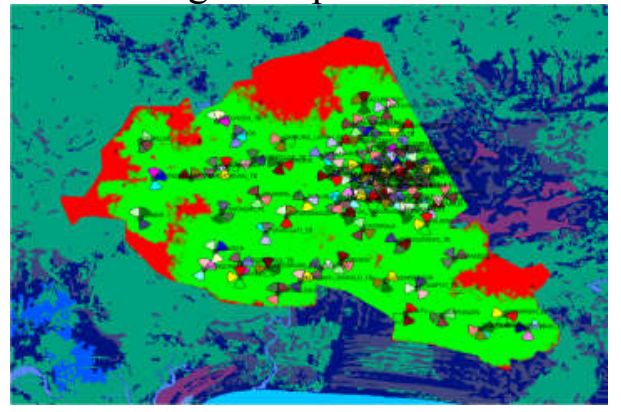

Gambar 4.4 prediksi trafik pelanggan Kabupaten Banyumas

Gambar 4.4 menunjukan kondisi pelanggan pada Kabupaten Banyumas, dimana ada 2 kondisi yaitu not connected dan connected. Pelanggan tersebut tersebar di beberapa wilayah cakupan dari area coverage LTE nya. Berikut hasil data statistik simulasi berdasarkan 
trafik pelanggan di Kabupaten Banyumas.

$$
\begin{aligned}
& \text { Total number of users trying to connect } \\
& \text { Active: Downlink 144,740 Uplink: 107,131 Downlink - Uplink: 35,513 } \\
& \text { Inactive: } 48,627 \\
& \text { Max Throughput Demand (DL) 3,541.41 Mbps } \\
& \text { UL: } \\
& \begin{array}{l}
\text { Max Throughput Demand (UL): } 2.585 .81 \text { Mbps } \\
\text { Min Throughput Demand (UL:) } 142.64 \text { Mbps }
\end{array} \\
& \text { Dari gambar }
\end{aligned}
$$

menunjukan bahwa total seluruh user yang melakukan aktivitas adalah 336.011 jiwa dengan detail pelanggan yang aktif melakukan downlink sebanyak 144.740 jiwa, pelanggan yang aktif melakukan proses uplink sebanyak 107.131 jiwa, pelanggan yang melakukan proses downlink dan uplink secara bersamaan sebesar 35513 jiwa dan pelanggan yang tidak melakukan aktivitas atau idle adalah sebesar 48627 jiwa.

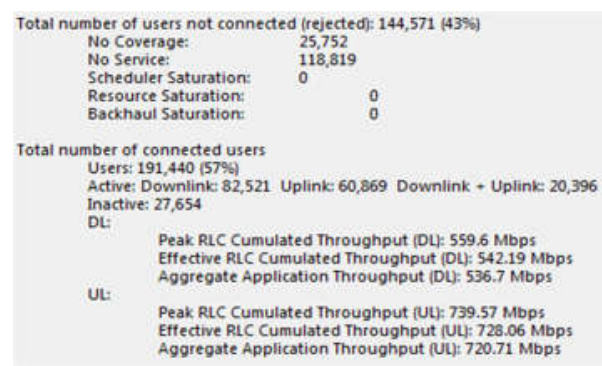

Gambar 4.6 Total pelanggan

connected \& not connected

Dari semua pelanggan yang di simulasikan oleh software atoll ada pelanggan yang ter-cover oleh jaringan dan ada juga yang tidak ter-cover. Hal ini disebabkan oleh terbatasnya jarak jangkauan pada antenna di setiap site-nya. Dari gambar 4.14 dapat dilihat bahwa hasil simulasi untuk user connected sebanyak 191440 jiwa (57\%) sedangkan untuk user not connected sebanyak 144571 jiwa $(43 \%)$.

User not connected disebabkan oleh beberapa hal, dalam simulasi ini disebabkan karena memang tidak ter-cover oleh jaringan dan tidak mendapatkan servis atau layanan.
Untuk user yang tidak ter-cover oleh jaringan LTE sebanyak 25752 jiwa dan untuk user yang tidak mendapatkan layanan sebanyak 118819 jiwa.

User yang berhasil

mendapatkan layanan atau user connected sebanyak 191440 jiwa. User connected terbagi menjadi 2 yaitu user active dan user inactive. User aktif merupakan user yang ter-cover oleh cakupan jaringan LTE dan melakukan aktivitas seluler atau dalam kata lain dedicated. User inactive ini mengindikasikan bahwa user tercover oleh jaringan LTE tetapi tidak melakukan aktivitas apapun atau dalam kata lain idle. User inactive yang didapat pada simulasi kali ini adalah sebanyak 27654 jiwa.

\subsection{Cost Benefit Analysis}

Selain aspek teknis pada penelitian ini juga akan membahas aspek cost benefit dimana ini akan saling terhubung. Aspek cost benefit meliputi CAPEX, OPEX \& NPV. CAPEX merupakan biaya yang dikeluarkan di awal penggelaran jaringan atau investasi. OPEX merupakan biaya yang dikeluarkan selama jaringan tersebut beroperasi. Setelah diperoleh hasil dari CAPEX \& OPEX untuk menghitung kelayakan penggelaran jaringan LTE di Kabupaten Banyumas dapat dihitung dengan NPV.

\subsubsection{Revenue}

Sebelum membahas nilai CAPEX, OPEX \& NPV perlu diketahui nilai revenue pada 5 tahun sebelum perencanaan untuk mementukan nilai prediksi revenue dalam 15 tahun kedepan. 
REVENUE SELURUH INDONESIA

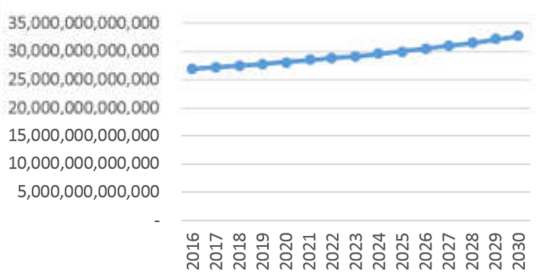

Gambar 4.7 Revenue seluruh Indonesia

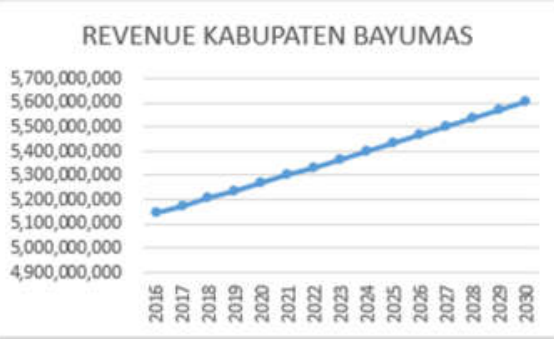

Gambar 4.8 Revenue Kabupaten Banyumas

Gambar 4.7 menunjukan proyeksi revenue yang dihasilkan operator Indosat untuk seluruh Indonesia menunjukan grafik menanjak dan memiliki pertumbuhan sebesar $1,3 \%$. Gambar 4.8 menunjukan revenue banyumas terus meningkat dari tahun 2016 hingga tahun 2030 dengan peningkatan sebesar $6,6 \%$. Dalam perhitungan cost benefit memerlukan data investasi diantaranya proyeksi jumlah eNodeB \& Investasi eNodeB.

\subsubsection{Komponen \& Proyeksi CAPEX}

CAPEX terdiri dari seluruh biaya yang dikeluarkan baik biaya perangkat, biaya installasi, maupun properti yang diperlukan untuk berdirinya sistem LTE serta mempunyai manfaat yang lebih dari satu periode akutansi.

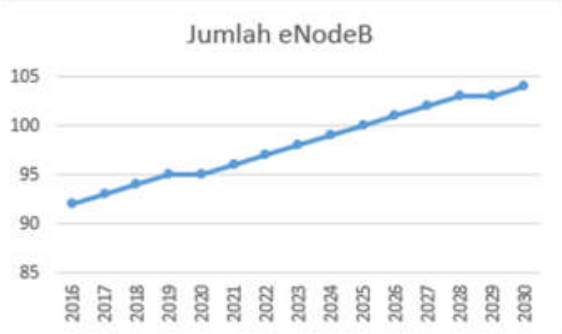

Gambar 4.9 proyeksi Jumlah eNodeB

Gambar 4.9 menunjukan proyeksi investasi eNodeB di tahun 2016 hingga tahun 2030 dimana investasi awal tahun 2016 sebanyak 92 enodeB dan mengalami peningkatan hingga 12 eNodeB. Hal tersebut disebabkan proyeksi pelanggan LTE di Kabupaten Banyumas meningkat sehingga eNodeB yang dibutuhkan selalu bertambah. Jumlah eNodeB yang digelar merupakan perhitungan dengan pendekatan kapasitas.

Asumsi harga eNodeB beserta instalasinya berdasarkan hasil studi kasus di PT Sinergi Aitikom adalah Rp 150.000.000,00 dengan perincian harga eNodeB \& license sebesar Rp140.000.000,00 dan Rp 10.000.000,00 untuk instalasinya. Harga tersebut asumsi bahwa perangkat LTE hanya di-insert ke dalam BTS existing operator yang terdapat sistem seluler $2 \mathrm{G}$, jadi tidak memerlukan biaya yang sangat besar untuk menambah perangkat pendukung lainnya. Hasil proyeksi penambahan eNodeB dari tahun 2016 hingga tahun 2030. Investasi pada awal tahun penggelaran jaringan memerlukan biaya yang sangat besar dimana 71 eNodeB secara bersamaan digelar di Kabupaten Banyumas. Sedangkan untuk tahun-tahun berikutnya mengikuti penambahan eNodeB berdasarkan proyeksi pendekatan kapasitas yang telah dihitung.

\subsubsection{Komponen \& Proyeksi OPEX}

Biaya OPEX ditentukan dari asumsi dan proyeksi berdasarkan annual report operator Indosat dari tahun 2011 hingga tahun 2015. Beberapa parameter yang menggunakan asumsi antara lain Operational Maintenance \& Sewa Backhaul. Sedangkan yang diproyeksikan menggunakan annual report Indosat antara lain biaya SDM, biaya Interconnection, Marketing dan administrasi umum. BHP 
frekuensi diperoleh dari buku publikasi kominfo. Berikut grafik hasil proyeksi tahun 2016 hingga tahun 2030 berdasarkan annual report operator indosat.

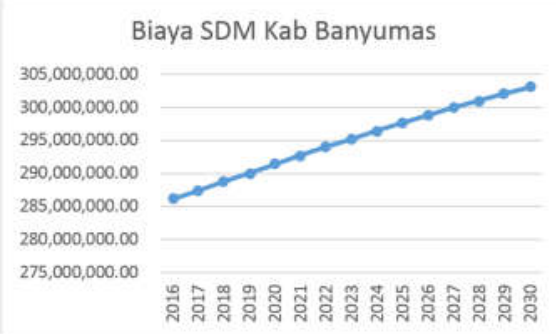

Gambar 4.10 Proyeksi SDM

Kabupaten Banyumas

Biaya SDM ini di dapat dari proyeksi annual report operator indosat. Prediksi kenaikan per tahun untuk biaya SDM di kabupaten bayumas sebesar 7,18\%. Biaya SDM yang dimaksudkan dalam hal ini adalah biaya gaji dari seluruh karyawan yang bekerja di wilayah Kabupaten Banyumas.

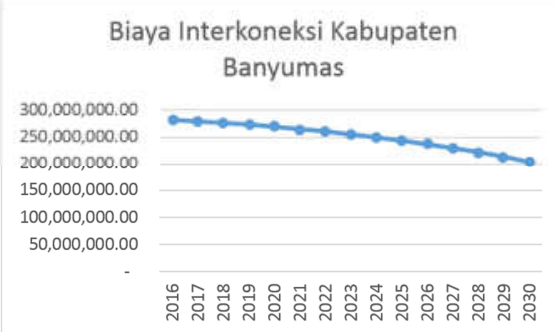

Gambar 4.11 Biaya Interkoneksi

Kabupaten Banyumas

Biaya interkoneksi terlihat menurun untuk setiap tahunnya dikarenakan penggunaan jaringan seluler antar sesama operator lebih mendominasi dibandingkan dengan lintas operator.penurunan di kabupaten banyumas memiliki rata-rata $6.12 \%$ per tahun.

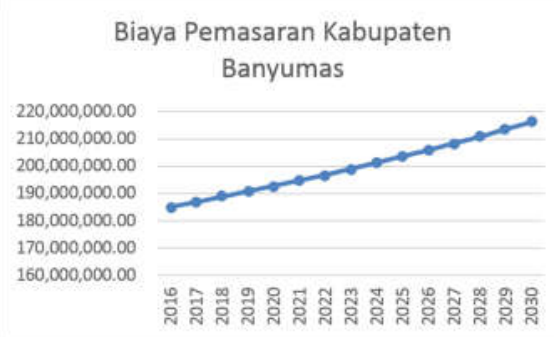

Gambar 4.12 Biaya Pemasaran

Kabupaten Banyumas

Biaya Pemasaran untuk kabupaten banyumas diprediksi akan selalu meningkat untuk setiap tahunnya sebesar rata-rata $4.86 \%$ per tahun. Biaya pemasaran merupakan biaya yang dibebankan untuk memasarkan produk kepada konsumen.

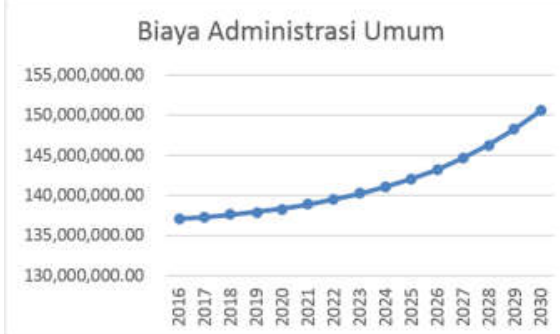

Gambar 4.13 Biaya Administrasi Umum

Biaya administrasi umum pada Kabupaten Banyumas juga mengalami kenaikan sebesar ratarata 3,44\%. Biaya administrasi umum itu sendiri merupakan biaya-biaya yang mengkoordinasikan kegiatankegiatan produksi dan pemasaran produk.

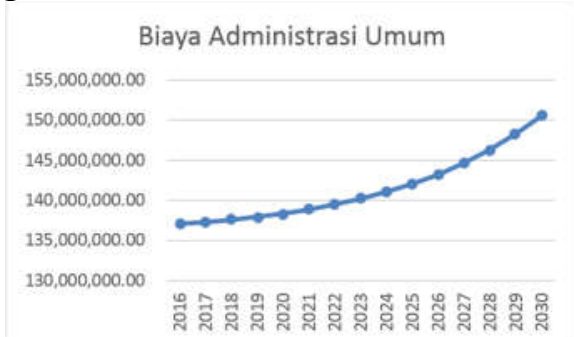

Gambar 4.14 Biaya Operational \& Maintenance

Biaya operational \& maintenance diasumsikan untuk satu bulannya sebesar Rp 1.800.000,00. Dari gambar 4.23 di atas dapat terlihat bahwa biaya operational \& maintenance terus bertambah, hal ini disebabkan oleh inflasi sebesar 3.35\%, maka biaya operational \& maintenance akan naik sebesar $3.35 \%$ setiap tahunnya.

Biaya Hak Pemakaian Frekuensi berlaku untuk skala nasional dimana nilai BHP untuk skala nasional adalah $\mathrm{Rp}$ 20.116.000.000,-/Mhz selama satu tahun pemakaian. Sehingga jika di proyeksikan untuk Kabupaten Banyumas maka 
diperlukan penyesuaian dengan perbandingan jumlah pelanggan seluruh Indonesia dengan jumlah pelanggan Kabupaten Banyumas dimana didapat nilai pelanggan Kabupaten Banyumas sebesar $0,17 \%$ dari jumlah keseluruhan pelanggan. Frekuensi yang digunakan dalam perancangan kali ini adalah $10 \mathrm{Mhz}$ maka :

BHP Banyumas =

$\left(\right.$ Rp 20.116.000.000*10Mhz)*( $\left.\frac{0,17}{100}\right)$

$$
=R p 360.111 .065,-
$$

Berikut Hasil proyeksi untuk BHP Frekuensi Banyumas selama 15 tahun kedepan.

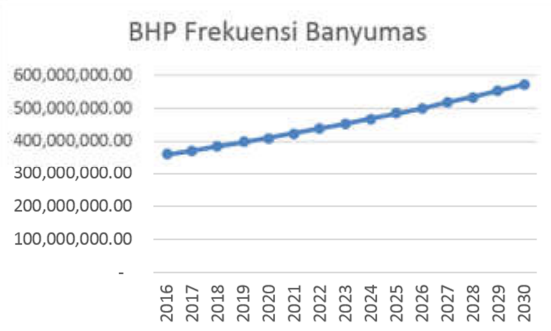

Gambar 4.15 BHP Frekuensi Banyumas

Dari gambar

menunjukan kenaikan biaya sewa frekuensi $10 \mathrm{MHz}$ mengikuti inflasi sebesar $3.35 \%$ per tahun. Selain BHP masih ada biaya sewa site. Dalam biaya sewa site diasumsikan $80 \%$ site milik sendiri dan 20\% sewa ke Tower Provider. Berikut hasil perhitungan proyeksi biaya sewa site dari tahun 2016 sampai dengan tahun 2030.

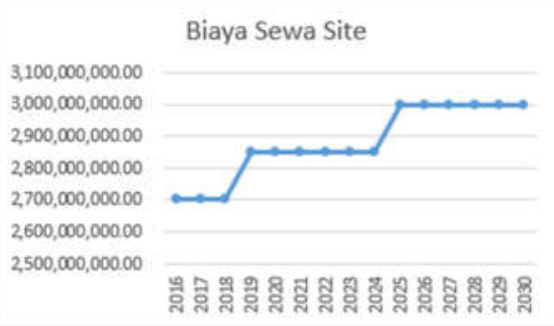

Gambar 4.16 Biaya Sewa Site

Biaya Sewa site lebih konstan dikarenakan penambahan jumlah eNodeB tidak terlalu signifikan. Biaya sewa site naik di tahun 2023 dimana di tahun tersebut eNodeB bertambah menjadi 19 eNodeB dimana pada awal perencanaan ditahun 2016 adalah 18 eNodeB.

\subsubsection{Analisis Kelayakan Investasi}

Analisis kelayakan investasi dapat dilihat dari hasil NPV \& IRR cash flow yang dihasilkan. Apabila NPV $>0$ maka proyek layak, $\mathrm{NPV}=0$ berarti perusahaan tidak mengalami keuntungan maupun kerugian NPV $<0$ maka perusahaan tidak layak. IRR merupakan indikator tingkat efisiensi dari suatu investasi. Suatu proyek layak apabila laju pengembaliannya (rate of return) lebih besar dari laju pengembalian Sebelum menentukan NPV \& IRR cashflow diperlukan asumsi finansial berupa parameter yang akan dijelaskan pada tabel 4.9 di bawah ini.

Tabel 4.9 Asumsi Finansial

\begin{tabular}{|c|c|c|}
\hline Parameter & Value & satuan \\
\hline Inflasi & $3.35 \%$ & per tahun \\
\hline $\begin{array}{l}\text { eNodeB }+ \\
\text { Software / license }\end{array}$ & $140,000,000$ & per NE \\
\hline Instalasi & $10,000,000$ & per NE \\
\hline $\mathrm{O} \& \mathrm{M}$ & $1,800,000.00$ & per bulan per NE \\
\hline $\begin{array}{l}\text { Backhaul } \\
\text { (Transport) }\end{array}$ & $10,000.00$ & $\begin{array}{r}\text { per Mbps, per site } \\
100 \mathrm{Mbps}\end{array}$ \\
\hline Sewa Site & $150,000,000.00$ & per tahun \\
\hline SDM & Annual Repport & Proyeksi tahunan \\
\hline Interconnection & Annual Repport & Proyeksi tahunan \\
\hline Marketing & Annual Repport & Proyeksi tahunan \\
\hline $\begin{array}{l}\text { General \& } \\
\text { Administrative }\end{array}$ & Annual Repport & Proyeksi tahunan \\
\hline BHP frekuensi & $\begin{array}{r}20,116,000,000.0 \\
0 \\
\end{array}$ & $\begin{array}{r}\text { Rupiah/Mhz Per } \\
\text { tahun }\end{array}$ \\
\hline Umur Depresiasi & 10 & Tahun \\
\hline Bunga pinjaman & $7.50 \%$ & per tahun \\
\hline $\begin{array}{l}\text { Masa } \\
\text { pengembalian } \\
\text { Pinjaman }\end{array}$ & 5 & tahun \\
\hline \multicolumn{3}{|l|}{$\begin{array}{l}\text { Struktur } \\
\text { Pendanaan } \\
\end{array}$} \\
\hline Pinjaman & $60 \%$ & \\
\hline $\begin{array}{l}\text { Modal } \\
\text { Sendiri } \\
\end{array}$ & $40 \%$ & \\
\hline Return on Equity & $20 \%$ & \\
\hline WACC & $12.5 \%$ & \\
\hline Tax & $25 \%$ & \\
\hline
\end{tabular}




\begin{abstract}
Dari tabel 4.9 dapat dijelaskan bahwa dalam penelitian ini bunga yang menjadi acuan adalah $7.5 \%$ per tahun untuk masa pengembalian hutang selama 5 tahun. Setelah didapat hasil dari proyeksi setiap parameter tersebut maka dapat diketahui nilai NPV \& IRR yaitu:
\end{abstract}

Tabel 4.10 Cost Benefit Analysis

\begin{tabular}{|c|c|}
\hline cost benefit analysis & value \\
\hline NPV & $-9,603,625,283.90$ \\
\hline IRR & $-7.98 \%$ \\
\hline \multicolumn{2}{|c|}{ Dari hasil penelitian in }
\end{tabular}
nilai NPV yang di dapat adalah Rp - 9.603.625.283,90 , hal tersebut menunjukan bahwa jaringan LTE dengan asumsi dan perhitungan proyeksi selama 15 tahun kedepan masih tidak layak dikarenakan nilai NPV $<0$. Dilihat dari nilai IRR yaitu sebesar -7.98\%, hal tersebut menunjukan bahwa dalam penggelaran jaringan LTE di Kabupaten Banyumas masih tidak efisien finansial.

Penggelaran jaringan LTE di Kabupaten Banyumas dianggap tidak layak dikarenakan oleh beberapa faktor diantaranya jumlah pelanggan LTE di Kabupaten Banyumas masih terlalu sedikit, tingginya biaya sewa site dan nilai ARPU yang masih terlalu rendah.

\section{DAFTAR PUSTAKA}

[1] Stallings, William.2007. "Komunikasi \& Jaringan Nirkabel jilid 2". Erlangga. Jakarta.

[2] UU Telekomunikasi nomor 36 Tahun 1999.

[3] Ardiyamto, Rudi. 2012. "Analisa Tekno Ekonomi Teknologi Jaringan LTE Berbasis FDD-TDD". Laporan Tesis. Bandung : Institute Teknologi Bandung.

[4] Hikmaturrokhman, Alfin. 2014. "4G
Handbook Edisi Bahasa Indonesia" Nulis Buku : Jakarta Selatan.

[5] Wardhana, Lingga. 2011. "2G/4G $R F$ Planning and Optimization for Consult". Nulis Buku : Jakarta Selatan.

[6] Banyumas Goverment. 2014. "Rencana Kerja Pemerintah Daerah (RKPD) Kabupaten Banyumas Tahun 2015" Kabupaten Banyumas.

[7] Riyansyah, Deris. 2010. "Analisa Kelayakan Migrasi BTS $3 G$ Berbasis WCDMA Menuju Jaringan LTE di DKI Jakarta (Studi Kasus : PT Telkomsel)" Laporan Tesis. Jakarta : Universitas Indonesia.

[8] Kusnendar, Jajang. 2010. "Multiplexing". Diktat kuliah komunikasi data.

[9] Hikmaturokhman, Alfin, and Achmad Rizal Danisya. "4G-LTE $1800 \mathrm{Mhz}$ coverage and capacity network planning using frequency reuse 1 model for rural area in Indonesia." Proceedings of the 6th International Conference on Software and Computer Applications. ACM, 2017.

[10] Nugraha, Toha Ardi, and Soo Young Shin. "Inter-Cell Interference Coordination in Heterogeneous Networks with Open Access of Small Cells." 대한전자공학회 학술대회 (2014): 446-449.

[11] Faria, Cezar. 2014. "The Future Mobile Broadband LTE/LTEAdvanced/5G". Dokumen PPT, [Online]

http://www.slideshare.net/cpqd/thefuture-of-mobile-broadband-lte-2014

[12] Arifi, Ilham. 2014. "Model Propagasi Kanal Radio Bergerak Pada GSM Frekuensi $900 \mathrm{MHz}$ di Daerah Taluk Kuantan" Laporan Tugas Akhir. Pekanbaru : Universitas Islam Negri Sultan Syarif Kasim Riau.

[13] Prasetyo, Imam, Muhammad Anif, Ari Sriyanto Nugroho, Subuh Pramono, Sarono Widodo, and Sidiq S. Hidayat. "Handover Analysis of Data and VoIP Services in 802.11 
b/g/n Wireless LAN." Indonesian Journal of Electrical Engineering and Computer Science 12, no. 11 (2014): 7832-7844

[14] Yudha, Dewa Made Mahendra, Pande Ketut Sudiarta, and E. R. Ngurah Indra. "Analisis Parameter Jaringan Hsdpa Kondisi Indoor Dengan Tems Investigation Dan G-Nettrack Pro." (2016).

[15] Usman Uke Kurniawan, Galuh Prihatmoko, dkk. 2012. "Fundamental Teknologi Seluler LTE”. Bandung: Rekayasa Sains.

[16] Inc Motorola. 2011. "LTE RF [17] Planning Guide Version:1.2.”: Motorola.

Fanani, Fikri Anshory. 2016. "Analisa Perencanaan Jaringan LTE (Long Term Evolution) FDD Frekuensi 900 Mhz dan 1800 Mhz Di Area Yogyakarta". Laporan Skripsi. Purwokerto: Sekolah Tinggi Teknologi Telematika Telkom

[18] Mobile Com Laboratory. "Carrier Aggregation Strategy for LTEAdvanced Radio Network Planning". Bandung: Universitas Telkom

[19] Pramitasari, Dyah Ayu. 2008. "Perencanaan dan analisis tekno ekonomi softswitch. Studi kasus HCPT di area Kalimantan". Laporan Tesis. Jakarta : Universitas Indonesia. 